\title{
Project-Based Research Learning (PBRL) Integrated With E-Learning in Projects Completion
}

\author{
https://doi.org/10.3991/ijet.v16i07.21193
}

\author{
Sumarmi, Syamsul Bachri, Listyo Yudha Irawan, \\ Muhammad Aliman \\ State University of Malang, Malang, Indonesia \\ Wan Ibrahim Wan Ahmad ${ }^{(凶)}$ \\ Asia Metropolitan University, Johor Bahru, Malaysia \\ wanibrahimeamu.edu.my
}

\begin{abstract}
Project-Based Research Learning (PBRL) is one of the learning models that stimulate students to be active and innovative in developing products. The purposes of this study were to determine 1) the influence of the PBRL integrated with e-learning on students' spatial thinking ability, 2) the influence of the PBRL integrated with e-learning on the students' ability to make disaster management projects, and 3) the influence of the PBRL integrated with e-learning on learning outcomes. The data analysis was used independent samples t-test from six essay questions and grading rubrics measurement. The results showed 1) a significant influence of the PBRL integrated with e-learning on students spatial thinking ability, 2) an influence of the PBRL integrated with e-learning on the students' ability to make disaster management projects, and 3) a significant influence of the PBRL integrated with e-learning on learning outcomes. The learning model is also effective as an alternative for distance learning.
\end{abstract}

Keywords-PBRL, E-Learning, Spatial Thinking, Learning Outcomes, Disaster Management

\section{$1 \quad$ Introduction}

There are many problems faced by students in applying scientific learning. Data collected that to support problem-solving management and to create a product is still limited by reading a book. Students were expected to collect data from secondary data of related institutions or in the field either through observation, interviews, or questionnaires. Also, the low creativity of students made them difficult to create products [1], [2].

In the future, the problem-solving ability will become increasingly important, and the need for physical skills will decrease. Figure 1 below indicates changes in labor skills requirements. The changes in workforce skills requirements showed in the following figure 1 . The changes in workforce skills needed in the future is the ability to solve problems (36\%), the social ability or collaborative skill $(19 \%)$, and the ability to 
process and finish tasks (18\%) [4]. Therefore, teacher need to facilitate and teach learning as pleasure that focuses on competencies, future skills, and character development [3].

The current assessment system is summative/punitive, standardizes the valuation, and the future situation of the assessment is formative/supporting the assessment based on the portfolio/project. Therefore, Indonesia now used new learning policies called 'Merdeka Belajar (The Free Leaning)'. The main strategies are to build 1) a technologybased national education platform that student-centered, interdisciplinary, relevant, project-based, and collaborative and 2) a future school/learning environment that safe and inclusive, can utilizing technology, collaborative, creative, and support experiential learning systems [5].

Many learning models can develop student competencies and capabilities, including Group investigation (GI), project-based learning (PBL), earth science in the community (Earthcomm), and project-based research learning (PBRL) [6], [7]. However, learning models that can develop student competencies based on research and can solve problems are project-based research learning models. [6] stated that the PBRL is an individual or group project carried out within a specified period to create a product, then the results were displayed or presented. While producing a qualified project, students were expected to do a research so that the PBRL model was needed. Tinsley, in [6], [8] suggested that project learning aimed to improve fieldwork skills, laboratory work, the ability to analyze, organize data, and make presentations.

Spatial thinking ability is needed for students to solve problems in research activity. It was because they have to solve authentic problems in multidisciplinary science. Besides, project-based learning supported students' spatial thinking to solve disaster problems with geography education [9]. [10], [11] argued that project-based learning focuses on solving daily authentic problems through direct learning experiences in the community and has a significant influence on students' spatial thinking ability. Moreover, project-based learning has interdisciplinary characteristics, was student-centered, and integrated with the latest issues [12]-[14].

The advantages of PBRL are to 1) increase students' learning motivation to do meaningful work, 2) increase problem-solving ability with a complexed area approach, 3) make students to be more active to solve complex problems, 4) improve collaboration, 5) encourage students to develop and practice the communication skills, 6) increase students ability in managing primary and secondary sources, 7) give students experience to manage the project and set time to complete the task, 8) provide learning experiences according to the latest issues, 9) make learning atmosphere to be more pleasant.

The subject was implemented using the blended learning model, specifically the elearning model. It is because e-learning has several advantages, such as increasing access and convenience, and improving the learning quality, reducing (or more flexible) costs [15], [16]. Also, e-learning could make the learning process to be more independent by utilizing materials available in the online system [17]. Teachers could add more enrichment topics online. Students' learning activities outside classroom could be managed and controlled well by the teachers [1], [18]. Moreover, it could reach students in 
a broad scope (potential to reach a global audience) and could facilitate the improvement and storage of learning materials (easy updating of content as well as has archive capabilities) [19]-[21].

Previous research related to project-based learning has been carried out by [14], [16], [22]-[28]. Also, previous studies that examined distance learning using blended learning have been carried out by [1], [15], [18]-[22], [29]-[32]. In addition, research about the ability of spatial thinking has also been investigated by [33]-[40].

However, there was limited research related to project-based research learning integrated with blended learning to determine the ability of spatial thinking and learning outcomes of student disaster management. Therefore, this study was conducted to find out:

1. The effect of project-based research learning integrated with e-learning on students' spatial thinking skills.

2. The effect of project-based research learning integrated with e-learning on the ability of students to create disaster management projects.

3. The effect of project-based research learning integrated with e-learning on learning outcomes.

\section{$2 \quad$ Literature Review}

\subsection{Project-Based Research Learning}

Project-Based Research Learning (PBRL) model is a project learning model that used problems as a first step to collect and integrate new knowledge based on experience in real activities. PBRL was designed to investigate and understand complex problems. Project learning is a systematic learning model that involves students to learn complex knowledge and skills, authentic questions and products, and assignments design [41]. It is an innovative learning and teaches the skills needed to succeed in the future [42].

Every individual has different motivation and ability to learn and regulated their environment so that learning will be more effective [11], [24]. Therefore, it is essential to manage learning conditions for the individual to have those attitudes and skills in learning, and the results could be maximized. PBRL is an example of a student-centered learning model aimed to develop students' independence, and it has an excellent response to the environment.

An ideal PBRL model used the inquiry learning strategy and the constructivist approach [23]. When PBRL is applied in learning, students will actively ask, predict, explain, and interact with concrete material using fundamental knowledge and applying it in the new practice. Lecturers make varied evaluations to represent student knowledge and improved the learning process. The learning was developed to make students be able to participate in discussions, solve problems, and exchange ideas and skills. The developed projects also had to be authentic and meaningful, relevant to student life, and related to the real world [36], [43], [44]. 
The objectives of implementing PBRL are to a) integrate learning with actual activities, b) make students learn in a directed method, (c) make students learn to work together (cooperative), (d) encourage students to do an investigation, (e) solve problems. The implementation of PBRL in Geography learning should mention (a) a meaningful problem in students' life, (b) essential and new issues, (c) complex and immediate problems that need to be solved, (d) a relevant problem for students, both in pedagogical and student contexts, (e) an original problem [43].

PBRL and GIS are the concepts and skills applied to investigate real-world issues. The learning starts with problems that were close to students. In this case, students acted as a planner, collaborators, producers, decision-makers, and presenters [43].

Table 1. The Role of Lecturers and Students in PBRL

\begin{tabular}{|l|l|l|}
\hline \multicolumn{1}{|c|}{ Step } & \multicolumn{1}{|c|}{ Lecturers' role } & \multicolumn{1}{c|}{ Students' role } \\
\hline \multirow{3}{*}{ PBRL } & Resource & Producer \\
\cline { 2 - 3 } & Model & Problem solver \\
\cline { 2 - 3 } & Guide & Planner \\
\cline { 2 - 3 } & Facilitator & Teacher for other students \\
\hline
\end{tabular}

The PBRL principles is same as project-based science [23]. PBRL is comprehensive learning designed to encourage students to research real problems [43]. The PBRL elements are 1) introduction, 2) definition of tasks, 3) procedures for investigation, 4) learning resource support, 5) task completion mechanism, 6) collaboration, and 7) reflection and transfer of activities [43]. PBRL is a learning model that applies theory, skills, techniques, and real-world solutions [26]. In learning Geography, the learning should be able to integrate with technology, activities/projects, and spatial thinking [23], [37].

The purpose of project-based learning was to improve skills such as fieldwork, laboratory work, the ability to analyze, organize data, and make presentations [34]. The skills acquired through this learning will significantly influence students' future careers through the learning process when they are in the group [45]. These include (1) being independent and original; the goal of curriculum development is to help students become independent, (2) having organizational skills; through project learning, students will develop effectively in planning, consulting, negotiating, arranging schedules, and other attitudes, (3) applying knowledge and skills, (4) having in-depth learning in important aspects, learning experiences, and problem-solving [46]. Also, students could demonstrate social competence, personal management, regulation of learning [43].

\subsection{Spatial thinking}

Spatial thinking is a form of thinking that requires cognitive skills. According to the National Research Council in [43], spatial thinking characteristics are as follows 1) having the habit of spatial thinking, 2) practicing spatial thinking through information since they have broad and deep spatial knowledge and concepts regarding spatial representation, 3) taking a critical attitude towards spatial thinking, 4) using spatial data to 
build, articulate, and maintain understanding or point of view in solving problems and answering questions.

From the study of various material substances, the study is always from a spatial perspective; producing geographic regions that characterize the similarities of objects, phenomena, patterns, problems, the earth surface's potential as a form of similarity (as well as differences) of objects, phenomena, patterns, problems, and earth surface's potential that presented and visualized. Taxonomy of spatial thinking is divided into 1) lower level: identity, describe, count, select, 2) higher level: explain, analyze, summarize, and 3) highest level: plan, predict, create [38].

Gersmehl in [49] also group 14 categories of spatial thinking and geographical skills into three groups: 1) lower-order, the first four spatial thinking and geographical skill codes include Location (LC), Condition (CD), Connection (CN), and Comparison (CP), 2) moderate-level, the fifth through the eighth spatial thinking and geographical skill codes include Influence (IF), Region (RG), Hierarchy (HR), Transition (TS), and 3) higher-order spatial thinking skills, the ninth through the fourteenth spatial thinking and geographical skills codes include Analog (AN) ), Pattern (PT), Association (AS), Exception (EX), Diffusion (DF), and Spatial model (SM).

\section{$3 \quad$ Method}

\subsection{Research design}

The research design was used a quasi-experimental with pretest post-test non-equivalent control group design. The independent variables were PBRL models with e-learning. Meanwhile, the dependent variables were the spatial thinking ability, the project completion ability, and the learning outcomes.

Table 2. Research Design

\begin{tabular}{|l|c|c|c|}
\hline \multicolumn{1}{|c|}{ Group } & Pretest & Treatment & Posttest \\
\hline Experiment (E) & $\mathrm{Q}_{1}$ & $\mathrm{X}$ & $\mathrm{Q}_{2}$ \\
\hline Control (C) & $\mathrm{Q}_{1}$ & - & $\mathrm{Q}_{2}$ \\
\hline
\end{tabular}

Source: [50]

Description

E : Experiment group

C : Control group

$\mathrm{O}_{1} \quad$ : Initial measurement in the pretest

$\mathrm{O}_{2} \quad$ : Final measurement in post-test

$\mathrm{X}$ : Treatment with PBRL by e-learning

- $\quad$ : Learning with discussion and question-answer method

\subsection{Participants}

The research subjects were the third-year students of the Disaster Geography course divided into four classes, namely A, B, K, and L, from the Geography Department of 
2017. Subjects were selected using purposive sampling technique because the score obtained in class A and B have the same average score from performance index in the last semester. The control group from class $\mathrm{K}$ was 32 students, and the experimental group from class L was 35 students. Both classes $\mathrm{K}$ and $\mathrm{L}$ were chosen because they have the same score, seen from the learning outcomes of the previous semester.

\subsection{Instrument and procedures}

Six essay questions were used to measure the variables of spatial thinking ability and learning outcomes, while an assessment rubric was used to measure the ability to do disaster-related projects. Students are given tests to measure spatial thinking skills and learning outcomes through pretest and posttest. The course is conducted for 16 meetings with four meetings in a group, and the rest is done through online meetings.

\subsection{Data analysis}

Before analyzing a hypothesis, normality and homogeneity tests are used before conducting a hypothesis test or prerequisite test. The normality prerequisite was measured using the Shapiro-Wilk test and the Kolmogorov Smirnov normality test to determine the distribution of data analysis. Homogeneity was measured using the Levene test to test the equality of variances. Data analysis was measured using the independent sample t-test with a significance level of $5 \%$. Statistical data analysis was obtained using SPPS software for windows version 23 .

\section{$4 \quad$ Result}

\subsection{The effect of PBRL integrated with E-learning on the spatial thinking ability}

The difference test for the two independent sample groups was carried out using the independent sample t-test. Before testing, normality premises were tested using the Kolmogorov Smirnov test. If the data used does not meet the premises, then it replaced using the Mann Whitney test. The analysis hypothesis was as follows:

- H0: There is no significant mean difference between the groups.

- H1: There are significant mean differences between groups.

Testing Criteria:

If the value of $\mathrm{t}_{\text {count }}>\mathrm{t}_{\text {table }}\left(\mathrm{Z}_{\text {count }} \leq \mathrm{Z}_{\text {table }}, \mathrm{Z}_{\text {count }}>\mathrm{Z}_{\text {table }}\right)$, and or $\rho$-value $<$ 0.05 , then $\mathrm{HO}$ is rejected.

If the value of $\mathrm{t}_{\text {count }}<\mathrm{t}_{\text {table }}$ (value $-\mathrm{Z}_{\text {table }}<\mathrm{Z}_{\text {count }}<\mathrm{Z}_{\text {table }}$ ), and or $\rho$-value $<$ 0.05 , then $\mathrm{HO}$ is accepted.

Based on the Kolmogorov-Smirnov normality test found that the significance value of the control group is $(0.015>0.005)$ and the experimental group is $(0.200>0.005)$. 
While the Shapiro-Wilk normality test obtained a significance value for the control group $(0.138>0.005)$ and the experimental group $(0.546>0.005)$.

Table 3. Descriptive Scores of Students Spatial Thinking Ability

\begin{tabular}{|l|c|c|c|c|c|c|c|c|}
\hline \multirow{2}{*}{ Group } & \multirow{2}{*}{$\mathbf{N}$} & Mean & \multirow{2}{*}{$\begin{array}{c}\text { Std. } \\
\text { Deviation }\end{array}$} & \multirow{2}{*}{ Std. Error } & \multicolumn{2}{c|}{$\begin{array}{c}\text { 95\% Confidence } \\
\text { Interval for Mean }\end{array}$} & \multirow{2}{*}{ Minimum } & Maximum \\
\cline { 5 - 8 } & & & & $\begin{array}{c}\text { Lower } \\
\text { Bound }\end{array}$ & $\begin{array}{c}\text { Upper } \\
\text { Bound }\end{array}$ & & \\
\hline Control & 37 & 6.5135 & 4.44486 & .73073 & 5.0315 & 7.9955 & -3.00 & 15.00 \\
\hline Experiment & 35 & 11.9429 & 3.28940 & .55601 & 10.8129 & 13.0728 & 5.00 & 19.00 \\
\hline Total & 72 & 9.1528 & 4.76093 & .56108 & 8.0340 & 10.2715 & -3.00 & 19.00 \\
\hline
\end{tabular}

Table 4. Mann-Whitney test of Students Spatial Thinking Ability

\begin{tabular}{|l|l|l|c|c|}
\hline \multicolumn{4}{|c|}{ Ranks } \\
\hline \multirow{4}{*}{$\begin{array}{l}\text { Gain score Spatial Think- } \\
\text { ing Ability }\end{array}$} & \multicolumn{1}{|c|}{ Group } & N & Mean Rank & Sum of Ranks \\
\cline { 2 - 5 } & Control & 37 & 24.96 & 923.50 \\
\cline { 2 - 5 } & Experiment & 35 & 48.70 & 1704.50 \\
\cline { 2 - 5 } & Total & 72 & & \\
\hline
\end{tabular}

Based on the Kolmogorov Smirnov normality test, it was found that the data of control and experimental group were not normally distributed with a significance value of less than $\alpha 5 \%$ each. Because it did not meet the premises, the Mann Whitney test was used.

Table 5. Statistic test of Students Spatial Thinking Ability

\begin{tabular}{|l|c|}
\hline \multicolumn{2}{|c|}{ Gain score Spatial Thinking Ability } \\
\hline Mann-Whitney U & 220.500 \\
\hline Wilcoxon W & 923.500 \\
\hline Z & -4.849 \\
\hline Asymp. Sig. (2-tailed) & .000 \\
\hline a. Grouping Variable: Group \\
\hline
\end{tabular}

From the Mann Whitney test, the calculated $\mathrm{Z}$ value was smaller than $-\mathrm{Z}$ table ($4.849<-1.960)$, and the $\rho$-value was lower than $\alpha(0.000<0.050)$. Then decided that $\mathrm{HO}$ is rejected, which means that there was a significant mean difference between groups based on spatial thinking ability gain score. The mean gain score of the experimental group was higher than the control group score, and the difference was significant.

The following are the results of different tests between the experimental class and the control class in the spatial thinking ability. 
Table 6. The Summary of Different Mean Tests of Students Spatial Thinking Ability

\begin{tabular}{|l|c|c|c|}
\hline \multicolumn{1}{|c|}{ Group } & Mean & St dev. & Significance of normality \\
\hline Control & 6,5135 & 4,44486 & 0,015 \\
\hline Experiment & 11.9429 & 3,28940 & 0,200 \\
\hline Z count & & $=-4,849$ \\
\hline Z table (5\%) & \multicolumn{2}{|c|}{$=1,960$} \\
\hline p-Value Z & & $=0,000$ \\
\hline
\end{tabular}

Based on Table 6 explained that the average score of spatial thinking ability in the experimental group is $11, .4$ and the average score of spatial thinking ability in the control group is 6.51 . The results support the analysis in Table 6 stated that there is a significant difference in the average score of spatial thinking ability between the two groups.

\subsection{The effect of PBRL integrated with E-learning in disaster management projects}

The following is the compatibility of the lecture program (Satuan Acara Perkuliahan) with e-learning in the control group showed in table 7.

Table 7. Online Courses to Support Project Completion in the Control Group

\begin{tabular}{|l|c|c|}
\hline \multicolumn{1}{|c|}{ The compatibility } & Frequency & Percentage \\
\hline Not supportive & 5 & 13.51 \\
\hline Less supportive & 16 & 43.24 \\
\hline Supportive & 1 & 2.70 \\
\hline Very supportive & 15 & 40.54 \\
\hline Total & 37 & 100.00 \\
\hline
\end{tabular}

Table 7 showed that the respondent answer was dominated by less supportive of $43.24 \%$ and very supportive by $40.5 \%$. While respondents chose to not supportive were $13.51 \%$.

The following are the frequency and percentage values for the support of online courses in completing disaster management projects in group experiments shown in table 8 .

Table 8. Online Courses to Support Project Completion in the Experiment Group

\begin{tabular}{|l|c|c|}
\hline \multicolumn{1}{|c|}{ The compatibility } & Frequency & Percentage \\
\hline Not supportive & 2 & 5.71 \\
\hline Less supportive & 13 & 37.14 \\
\hline Supportive & 12 & 34.29 \\
\hline Very supportive & 8 & 22.86 \\
\hline Total & 35 & 100.00 \\
\hline
\end{tabular}


Based on table 8, the highest frequency is found in disagreeing with 13 answers or $37.14 \%$, followed by the lowest frequency found in strongly disagree with two answers or $5.71 \%$.

\subsection{The effect of PBRL model integrated with E-learning on learning outcomes}

The gain scores of learning outcomes were tested using Kolmogorov-Smirnov normality test and Shapiro-Wilk normality test. Based on the Kolmogorov-Smirnov normality test found that the significance value of the control group is $(0.003>0.005)$ and the experimental group is $(0.200>0.005)$. While the Shapiro-Wilk normality test obtained a significance value for the control group $(0.123>0.005)$ and the experimental group $(0.572>0.005)$.

Table 9. Descriptive scores of Learning Outcomes

\begin{tabular}{|c|c|c|c|c|c|c|c|c|}
\hline \multicolumn{9}{|c|}{ Descriptive } \\
\hline \multicolumn{9}{|c|}{ Gain score of Students Spatial Thinking Ability } \\
\hline \multirow{2}{*}{ Group } & \multirow{2}{*}{$\mathbf{N}$} & \multirow{2}{*}{ Mean } & \multirow{2}{*}{$\begin{array}{c}\text { Std. } \\
\text { Deviation }\end{array}$} & \multirow{2}{*}{ Std. Error } & \multicolumn{2}{|c|}{$\begin{array}{l}\text { 95\% Confidence In- } \\
\text { terval for Mean }\end{array}$} & \multirow{2}{*}{ Minimum } & \multirow{2}{*}{ Maximum } \\
\hline & & & & & $\begin{array}{l}\text { Lower } \\
\text { Bound }\end{array}$ & $\begin{array}{l}\text { Upper } \\
\text { Bound }\end{array}$ & & \\
\hline Control & 37 & 6.8919 & 3.16916 & .52101 & 5.8352 & 7.9485 & .00 & 13.00 \\
\hline Experiment & 35 & 12.7143 & 3.48587 & .58922 & 11.5168 & 13.9117 & 6.00 & 20.00 \\
\hline Total & 72 & 9.7222 & 4.41579 & .52041 & 8.6846 & 10.7599 & .00 & 20.00 \\
\hline
\end{tabular}

Table 10. Mann-Whitney test of Learning Outcomes

\begin{tabular}{|l|l|l|l|l|}
\hline \multicolumn{5}{|c|}{ Ranks } \\
\hline \multirow{4}{*}{$\begin{array}{l}\text { Gain score Spatial Thinking } \\
\text { Ability }\end{array}$} & \multicolumn{1}{|c|}{ Nroup } & \multicolumn{1}{c|}{ Mean Rank } & Sum of Ranks \\
\cline { 2 - 5 } & Control & 37 & 22.80 & 843.50 \\
\cline { 2 - 5 } & Experiment & 35 & 50.99 & 1784.50 \\
\cline { 2 - 5 } & Total & 72 & & \\
\hline
\end{tabular}

Based on the Kolmogorov Smirnov normality test, it was found that the control and experimental group data were not normally distributed with a significance value of less than $\alpha 5 \%$ each. Because it did not meet the premises, the Mann Whitney test was used.

Table 11. Statistic test of Learning Outcomes

\begin{tabular}{|l|c|}
\hline \multicolumn{2}{|c|}{ Gain score Spatial Thinking Ability } \\
\hline Mann-Whitney U & 140.500 \\
\hline Wilcoxon W & 843.500 \\
\hline Z & -5.747 \\
\hline Asymp. Sig. (2-tailed) & .000 \\
\hline a. Grouping Variable: Group & \\
\hline
\end{tabular}

From the Mann Whitney test, the calculated $\mathrm{Z}$ value was smaller than $-\mathrm{Z}$ table ($5.747<-1.960)$, and the $\rho$-value was lower than $\alpha(0.000<0.050)$. Then decided that H0 
is rejected, which means that there was a significant mean difference between groups based on leaning outcomes gain score. Seen from Table 11, the mean gain score of the experimental group was higher than the control group score, and the difference was significant. Based on the Kolmogorov Smirnov normality test, it was found that the control and experimental group data were not normally distributed with a significance value of less than $\alpha 5 \%$ each. Because it did not meet the premises, the Mann Whitney test was used.

The analysis of different mean tests of learning outcomes in the control and experiment groups showed in the following table 12.

Table 12. The Summary of Different Mean Tests of Learning Outcomes

\begin{tabular}{|l|c|c|c|}
\hline \multicolumn{1}{|c|}{ Group } & Mean & St dev. & Significance of normality \\
\hline Control & 6.8919 & 3.16916 & 0,003 \\
\hline Experiment & 12.7143 & 3.48587 & 0.200 \\
\hline$Z$ count & & $=-5.747$ \\
\hline$Z$ table $(5 \%)$ & & $=1.960$ \\
\hline p-value $Z$ & & \\
\hline
\end{tabular}

Based on Table 12 explained that the average score of learning outcome in the experimental group is 12.71 , and the average score of learning outcome in the control group is 6.89. It can be concluded that the average score of learning outcomes in the experimental group was higher than the average score in the control group. The results of the Mann-Whitney test in table 14 stated that there is a significant difference in the average score of learning outcomes in the disaster geography course between the experimental group and the control group.

\section{Discussion}

\subsection{The effect of PBRL on spatial thinking ability}

PBRL that is integrated with e-learning has a significant effect on spatial thinking ability. It was seen from the mean gain score of the experiment group was higher and significantly different from the control group. Data searching for Project-Based Research Learning was supported by online data, especially from institutions that related to disaster issues.

The result also supported by the study [41] that showed from LSD test (Least Significant Different) about project-based learning can affect the increase of students' motivation up to $14 \%$, student creativity of $31.1 \%$, and critical thinking skills of $34 \%$. It also increased the students' cognitive abilities by $28.9 \%$ of the learning provided without the project. It is also supported by the results of the study by [28] that the syntax of project learning could be very related to the research stages. It was aligned with the steps in the scientific approach, which is a learning process that requires students to move. It means that learning projects preceded by research will have a maximal result. 
The results of the study [51] show that there was an influence of project-based learning on students' problem-solving skills.

Research by [22], [52] showed that there was an influence of research-based learning approaches on students' critical thinking skills. The results showed interpretation (75.00\%), analysis (69.06\%), evaluation (78.57\%), inference (65.48\%), and explanation $(62.05 \%)$ with an average of all by $70.13 \%$ so that it was categorized as high. In the experiment group, the $\mathrm{N}-\mathrm{Gain}$ value was 0.53 , while in the control group, the $\mathrm{N}$ Gain value was 0.35 , categorized as moderate.

The results from other studies also supported this research that the introduction, application, and demonstration of appropriate geospatial technology can strengthen learning and facilitated the absorption of new cognitive skills [35], [53]. Based on the literature review, it can be concluded that spatial intelligence plays a role in increasing students' disaster preparedness. The learning strategy used is the optimization of eight spatial ability to improve disaster literacy are (1) comparison; (2) buffer (range); (3) region; (4) gradient (transition); (5) hierarchy; (6) analogy; (7) patterns; and (8) associations (relationships). This strategy is expected to reduce natural disaster fatalities among high school students [39].

\subsection{The effect of PBRL integrated with e-learning to support project completion}

Data analysis revealed that PBRL integrated with e-learning is very supportive to complete individual projects because students could search the source independently. The e-learning model is categorized as supportive. The completion of group assignments is slower than the individual because the coordination is somewhat less smooth using online messaging.

The results were supported by the study [31], [32], [54] stated that the PBRL integrated with e-learning, has advantages to 1) increase access and convenience, 2) improve the quality of learning, and 3) reduce (or more flexible) costs. Also, e-learning could make the learning process to be more independent by utilizing materials available in the online system. Teachers could add more enrichment topics online. Moreover, distance learning that is designed using blended learning can also provide knowledge on disaster risk reduction and disaster management [55].

\subsection{The effect of PBRL integrated with e-learning on learning outcomes}

The results concluded that the PBRL integrated with e-learning had a significant effect on learning outcomes. It was seen from the mean gain score of the experiment group was higher and significantly different from the control group. The lecturers could gain better knowledge and skills to assess disaster teaching management based on research. They also have improved skills to plan for project design and to build assessment instruments for learning [5], [56], [57]. Initially, lecturers need to provide a good explanation of what criteria are used to assess the projects made by students.

Inquiry, innovative and collaborative learning provides knowledge and abilities to complete planned projects [42]. In designing and making products, indirect knowledge 
and skills are needed [57]. At the final stage of this learning, students are required to have communication skills to present the projects [53]. It is necessary to direct the research guidance before starting on disaster management projects and to connect with local disasters in each region [5], [58]. the division of group assignment needed to have equalized abilities, especially for students who were lacking.

\section{Conclusion and Implication}

Based on the results and discussion related to the implementation of project-based research, learning can be concluded: 1) The PBRL integrated with e-learning has a significant effect on spatial thinking ability. It was seen from the mean gain score of the experiment group was higher and significantly different from the control group. 2) Elearning has to support personal or individual projects. It is because students could search for online sources anytime and anywhere without being influenced by others so that it is categorized as supportive. 3) The PBRL integrated with e-learning has a significant effect on learning outcomes. It was seen from the mean gain score of the experiment group was higher and significantly different from the control group.

The results have implications for teachers to use the PBRL model integrated with blended learning during the COVID-19 pandemic period. The blended learning must use only one type of learning management system so that learning will be more effective. Further research can be developed using other cognitive variables to determine their effects. Also, research on the development of teaching materials of e-modules is needed to support this research. The application of the model does not reduce the ability of spatial thinking, project completion, and student learning outcomes for the online meeting.

\section{$7 \quad$ References}

[1] A.-M. Nortvig, A. K. Petersen, and S. H. Balle, "A Literature Review of the Factors Influencing E-Learning and Blended Learning in Relation to Learning Outcome, Student Satisfaction and Engagement," Electron. J. E-Learn., vol. 16, no. 1, pp. 46-55, 2018.

[2] R. M. Sari, S. Sumarmi, I. K. Astina, D. H. Utomo, and R. Ridhwan, "Measuring Students Scientific Learning Perception and Critical Thinking Skill Using Paper-Based Testing: School and Gender Differences," Int. J. Emerg. Technol. Learn. IJET, vol. 14, no. 19, Art. no. 19, Oct. 2019. https://doi.org/10.3991/ijet.v14i19.10968

[3] Ministry of Education and Culture, Peta Jalan Pendidikan Indonesia 2020-2035 (Indonesian Education Road Map for 2020-2035). 2020.

[4] Future of Jobs Survey, World Economic Forum, "Skills Stability," The Future of Jobs. http://wef.ch/2f76eyI (accessed Jun. 12, 2020).

[5] S. Sumarmi, S. Bachri, L. Y. Irawan, D. B. P. Putra, R. Risnani, and M. Aliman, "The Effect of Experiential Learning Models on High School Students Learning Scores and Disaster Countermeasures Education Abilities," J. Educ. Gift. Young Sci., vol. 8, no. 1, Art. no. 1, Mar. 2020. https://doi.org/10.17478/jegys.635632

[6] S. Sumarmi, Model-Model Pembelajaran Geografi (Geography Learning Models). Yogjakarta: Aditya Media, 2012. 
[7] S. Sumarmi, S. Bachri, A. Baidowi, and M. Aliman, "Problem-Based Service Learning's Effect on Environmental Concern and Ability to Write Scientific Papers," Int. J. Instr., vol. 13, no. 4, 2020. doi: 10.29333/iji.2020.13411a

[8] B. Trilling and P. Hood, "Learning, Technology, and Education Reform in the Knowledge Age or 'We're Wired, Webbed, and Windowed, Now What?'” Educ. Technol., vol. 39, no. 3, pp. 5-18, 1999.

[9] K. Ohnishi and H. Mitsuhashi, "Geography Education Challenges Regarding Disaster Mitigation in Japan,” Rev. Int. Geogr. Educ. Online, vol. 3, no. 3, Art. no. 3, 2013.

[10] E. B. Johnson, Contextual Teaching and Learning: What It Is and Why It's Here to Stay. Corwin Press, 2002.

[11] D. Jonassen, T. Mayes, and R. McAleese, "A Manifesto for a Constructivist Approach to Uses of Technology in Higher Education," in Designing Environments for Constructive Learning, T. M. Duffy, J. Lowyck, D. H. Jonassen, and T. M. Welsh, Eds. Berlin, Heidelberg: Springer, 1993, pp. 231-247. https://doi.org/10.1007/978-3-642-78069-1_12

[12] G. H. Brown, "A Group-learning Approach to Academic and Transferable Skills Through an Exercise in the Global Positioning System," J. Geogr. High. Educ., vol. 23, no. 3, pp. 291-301, Nov. 1999, doi: 10.1080/03098269985254.

[13] J. S. Brown, A. Collins, and P. Duguid, "Situated Cognition and the Culture of Learning," Educ. Res., vol. 18, no. 1, pp. 32-42, Jan. 1989, doi: 10.3102/0013189X018001032.

[14] M. L. Nation, "Project-Based Learning for Sustainable Development," J. Geogr., vol. 107, no. 3, pp. 102-111, Nov. 2008, doi: 10.1080/00221340802470685.

[15] C. Banditvilai, "Enhancing Students' Language Skills through Blended Learning," Electron. J. E-Learn., vol. 14, no. 3, pp. 220-229, 2016.

[16] W. Kamdi, "Project-based learning: pendekatan pembelajaran inovatif (Project-based learning: innovative learning approaches)," Malang Univ. Negeri Malang, 2008.

[17] I. Jung, T. Wong, and T. Belawati, Quality Assurance in Distance Education and E-Learning: Challenges and Solutions from Asia. B-42, Panchsheel Enclave, New Delhi 110017 India: SAGE Publications India Pvt Ltd, 2013.https://doi.org/10.4135/9788132114079

[18] S. Y. Ju and S. Y. Mei, "Perceptions and Practices of Blended Learning in Foreign Language teaching at USIM," Eur. J. Soc. Sci. Educ. Res., vol. 12, no. 1, p. 170, Mar. 2018. https://doi.org/10.26417/ejser.v12i1.p170-176

[19] D. R. Garrison and N. D. Vaughan, Blended Learning in Higher Education: Framework, Principles, and Guidelines. John Wiley \& Sons, 2008.

[20] Y. C. Lee, K. Lau, and V. W. Y. Yip, "Blended learning for building student-teachers' capacity to learn and teach science-related interdisciplinary subjects: The case of Hong Kong," Asian Assoc. Open Univ. J., vol. 11, no. 2, pp. 166-181, Jan. 2016. https://doi.org/10. 1108/aaouj-09-2016-0029

[21] S. Wichadee, "A Development of the Blended Learning Model Using Edmodo for Maximizing Students' Oral Proficiency and Motivation," Int. J. Emerg. Technol. Learn. IJET, vol. 12, no. 02, p. 137, Feb. 2017. https://doi.org/10.3991/ijet.v12i02.6324

[22] H. A. Arina, F. Munawaroh, I. Rosidi, and Y. Hidayati, "Peningkatan Keterampilan Berpikir Kritis Siswa Melalui Pendekatan Pembelajaran Berbasis Riset" (Improving Students' Critical Thinking Skills Through Research-Based Learning Approaches)," Nat. Sci. Educ. Res., vol. 2, no. 1, Art. no. 1, Jul. 2019. https://doi.org/10.19166/johme.v2i2.1331

[23] P. C. Blumenfeld, E. Soloway, R. W. Marx, J. S. Krajcik, M. Guzdial, and A. Palincsar, "Motivating Project-Based Learning: Sustaining the Doing, Supporting the Learning," Educ. Psychol., vol. 26, no. 3-4, pp. 369-398, Jun. 1991, doi: 10.1080/00461520.1991.9653139. https://doi.org/10.1207/s15326985ep2603\&4_8

[24] M. M. Grant and R. M. Branch, "Project-Based Learning in a Middle School," J. Res. Technol. Educ., vol. 38, no. 1, pp. 65-98, Sep. 2005, doi: 10.1080/15391523.2005.10782450.

[25] D. Insyasiska, S. Zubaidah, and H. Susilo, "Pengaruh Project Based Learning Terhadap Motivasi Belajar, Kreativitas, Kemampuan Berpikir Kritis, Dan Kemampuan Kognitif Siswa 
Pada Pembelajaran Biologi" (The Effect of Project Based Learning on Learning Motivation, Creativity, Critical Thinking Ability, and Cognitive Ability of Students in Biology Learning)," J. Pendidik. Biol., vol. 7, no. 1, Art. no. 1, Apr. 2017, doi: 10.17977/um052v7i1p921. https://doi.org/10.29407/jbp.v6i2.14790

[26] A. Makrufi, A. Hidayat, and M. Muhardjito, "Pengaruh Model Pembelajaran Berbasis Proyek terhadap Kemampuan Pemecahan Masalah Pokok Bahasan Fluida Dinamis" (The Effect of Project-Based Learning Models of the Problem-Solving ability on Dynamic Fluid Subjects)," J. Pendidik. Teori Penelit. Dan Pengemb., vol. 3, no. 7, Art. no. 7, Jul. 2018, doi: 10.17977/jptpp. v3i7.11291. https://doi.org/10.26877/jp2f.v5i1.2568

[27] G. Paschalis, "A Compound LAMS-MOODLE Environment to Support Collaborative Project-Based Learning: A Case Study with the Group Investigation Method,” Turk. Online J. Distance Educ., vol. 18, no. 2, Art. no. 2, 2017. https://doi.org/10.17718/tojde.306565

[28] M. A. Umar, "Penerapan pendekatan saintifik dengan metode Pembelajaran berbasis proyek (project-based learning) Dalam materi ekologi" (Application of a scientific approach to the project-based learning method in ecological subject)," Bionatural J. Ilm. Pendidik. Biol., vol. 4, no. 2, Art. no. 2, Aug. 2018, Accessed: Jun. 11, 2020. [Online]. Available: https://www.ejournal.stkipbbm.ac.id/index.php/bio/article/view/194.

[29] J. C. Cronje, "Towards a New Definition of Blended Learning," Electron. J. E-Learn., vol. 18 , no. 2,2020

[30] K. Gynther, "Design Framework for an Adaptive MOOC Enhanced by Blended Learning: Supplementary Training and Personalized Learning for Teacher Professional Development.," Electron. J. E-Learn., vol. 14, no. 1, pp. 15-30, 2016.

[31] A. Nurkhin, K. Kardoyo, H. Pramusinto, R. Setiyani, and R. Widhiastuti, "Applying Blended Problem-Based Learning to Accounting Studies in Higher Education; Optimizing the Utilization of Social Media for Learning," Int. J. Emerg. Technol. Learn. IJET, vol. 15, no. 08, Art. no. 08, Apr. 2020. https://doi.org/10.3991/ijet.v15i08.12201

[32] R. H. Rafiola, P. Setyosari, C. L. Radjah, and M. Ramli, "The Effect of Learning Motivation, Self-Efficacy, and Blended Learning on Students' Achievement in The Industrial Revolution 4.0," Int. J. Emerg. Technol. Learn. IJET, vol. 15, no. 08, Art. no. 08, Apr. 2020. https://doi.org/10.3991/ijet.v15i08.12525

[33] M. Aliman, Budijanto, Sumarmi, K. Astina, R. E. Putri, and M. Arif, "The Effect of Earthcomm Learning Model and Spatial Thinking Ability on Geography Learning Outcomes," J. Balt. Sci. Educ., vol. 18, no. 3, p. Continuous, 2019. https://doi.org/10.33225/jbse/19.18.323

[34] M. Aliman, T. Ulfi, S. Lukman, and M. Hujairah Hi, "Konstruksi Tes Kemampuan Berpikir Spasial Model Sharpe-Huynh" (The Construction of Spatial Thinking Ability on SharpeHuynh Model)," J. Georafflesia Artik. Ilm. Pendidik. Geogr., vol. 4, no. 1, pp. 1-11, 2019. doi: 10.32663/georaf.v4i1.738

[35] K. B. Berse, F. Bendimerad, and Y. Asami, "Beyond geo-spatial technologies: promoting spatial thinking through local disaster risk management planning," Procedia-Soc. Behav. Sci., vol. 21, pp. 73-82, 2011. https://doi.org/10.1016/j.sbspro.2011.07.037

[36] B. A. Chun, Geographical perspectives strengthened by GIS in an interdisciplinary curriculum: Empirical evidence for the effect on environmental literacy and spatial thinking ability. State University of New York at Buffalo, 2008.

[37] P. Hadi, "Menyemai Kemampuan Berfikir Spasial (Improving Spatial Thinking Ability)," 2012, [Online]. Available: https://fkip.uns.ac.id/2013/07/daftar-prosiding/.

[38] I. Jo and S. W. Bednarz, "Textbook Questions to Support Spatial Thinking: Differences in Spatiality by Question Location,” J. Geogr., vol. 110, no. 2, pp. 70-80, Mar. 2011, https://doi.org/10.1080/00221341.2011.521848

[39] S. G. Marlyono and F. Urfan, "Optimalisasi kecerdasan spasial untuk meningkatkan kesiapsiagaan bencana" (Optimizing spatial intelligence to improve disaster preparedness)," in Seminar Nasional Peningkatan Mutu Pendidikan, 2019, vol. 1, no. 1. 
[40] M. Nursa'ban, K. Kumaidi, and M. Mukminan, "Factors of Critical Spatial Thinking for a Geography Metacognition Assessment in Indonesian Senior High Schools,” Rev. Int. Geogr. Educ. Online, vol. 10, no. 2, Art. no. 2, 2020. https://doi.org/10.33403/rigeo.686050

[41] D. Insyasiska, S. Zubaidah, and H. Susilo, "Pengaruh Project Based Learning Terhadap Motivasi Belajar, Kreativitas, Kemampuan Berpikir Kritis, Dan Kemampuan Kognitif Siswa Pada Pembelajaran Biologi" (The Effect of Project Based Learning on Learning Motivation, Creativity, Critical Thinking Ability, and Cognitive Ability of Students in Biology Learning),"” J. Pendidik. Biol., vol. 7, no. 1, Art. no. 1, Apr. 2017, doi: 10.17977/um052v7i1p921. https://doi.org/10.29407/jbp.v6i2.14790

[42] S. Bell, "Project-Based Learning for the 21 st Century: Skills for the Future," Clear. House J. Educ. Strateg. Issues Ideas, vol. 83, no. 2, pp. 39-43, Jan. 2010, doi: $10.1080 / 00098650903505415$

[43] R. H. Audet and L. K. Jordan, Integrating Inquiry Across the Curriculum. Corwin Press, 2005.

[44] T. A. Keiper, "GIS for Elementary Students: An Inquiry into a New Approach to Learning Geography,” J. Geogr., vol. 98, no. 2, pp. 47-59, Mar. 1999. https://doi.org/10.1080/ $\underline{00221349908978860}$

[45] D. A. Kolb, Experiential Learning: Experience as the Source of Learning and Development. FT Press, 2014

[46] D. W. Johnson, R. T. Johnson, and M. B. Stanne, "Cooperative learning methods: a metaanalysis. 2000," Available Coop. Learn. Cent. Website Httpwww Clcrc Compagesclmethods Html, 2007.

[47] E. Maryani, “'Geografi Dalam Perspektif keilmuan dan pendidikan di Persekolahan (The Perspective of Geography as Science and Education in University),"” p. 39, 2006.

[48] R. H. Audet and K. L. Jordan, Integrating Inquiry Across the Curriculum. Corwin Press, 2005.

[49] B. Handoyo and P. Purwanto, Pembelajaran Berbasis Spasial dan Implementasinya: Inovasi Pembelajaran (Learning based on spatial and its implementation: Learning Innovation). Malang: UM Press, 2017.

[50] S. Arikunto, Dasar-dasar evaluasi pendidikan (Fundamentals of educational evaluation). Bumi Aksara, 1999.

[51] A. Makrufi, A. Hidayat, and M. Muhardjito, "Pengaruh Model Pembelajaran Berbasis Proyek terhadap Kemampuan Pemecahan Masalah Pokok Bahasan Fluida Dinamis" (The Effect of Project-Based Learning Models of the Problem-Solving ability on Dynamic Fluid Subjects),"' J. Pendidik. Teori Penelit. Dan Pengemb., vol. 3, no. 7, Art. no. 7, Jul. 2018, doi: 10.17977/jptpp. v3i7.11291. https://doi.org/10.26877/jp2f.v5i1.2568

[52] S. Marni, Suyono -, Roekhan -, and T. Harsiati, "Critical Thinking Patterns of First-Year Students in Argumentative Essay,” J. Educ. Gift. Young Sci., vol. 7, no. 3, Art. no. 3, Sep. 2019, doi: 10.17478/jegys.605324.

[53] M. Aliman, Budijanto, Sumarmi, I. K. Astina, R. E. Putri, and M. Arif, "The Effect of Earthcomm Learning Model and Spatial Thinking Ability on Geography Learning Out-comes," J. Balt. Sci. Educ., vol. 18, no. 3, pp. 323-334, Jun. 2019, https://doi.org/10.33225/ jbse/19.18.323

[54] K. Gynther, "Design Framework for an Adaptive MOOC Enhanced by Blended Learning: Supplementary Training and Personalized Learning for Teacher Professional Development," Electron. J. E-Learn., vol. 14, no. 1, pp. 15-30, 2016.

[55] S. Ahmad and S. Md. Numan, "Potentiality of Disaster Management Education through Open and Distance Learning System in Bangladesh Open University," Turk. Online J. Distance Educ., vol. 16, no. 1, pp. 249-260, 2015. https://doi.org/10.17718/tojde.24161

[56] R. M. Sari, S. Sumarmi, I. K. Astina, D. H. Utomo, and R. Ridhwan, "Measuring Students Scientific Learning Perception and Critical Thinking Skill Using Paper-Based Testing: 
School and Gender Differences," Int. J. Emerg. Technol. Learn. IJET, vol. 14, no. 19, pp. 132-149, Oct. 2019. https://doi.org/10.3991/ijet.v14i19.10968

[57] S. Amin, S. Sumarmi, S. Bachri, S. Susilo, and A. Bashith, "The Effect of Problem-Based Hybrid Learning (PBHL) Models on Spatial Thinking Ability and Geography Learning Outcomes," Int. J. Emerg. Technol. Learn. IJET, vol. 15, no. 19, Art. no. 19, Oct. 2020. https://doi.org/10.3991/ijet.v15i19.15729

[58] D. W. L. Hung and A. F. L. Wong, "Activity Theory as a Framework for Project Work in Learning Environments," Educ. Technol., vol. 40, no. 2, pp. 33-37, 2000

\section{Authors}

Sumarmi is a professor, researcher and senior lecturer. Expert in Environmental Geography, Geography Education and Local Wisdom. Affiliation: Department of Geography, Faculty of Social Sciences, State University of Malang Jl. Semarang No. 5, East Java, Indonesia. Email: sumarmi.fis@um.ac.id. Scopus id: 57201353799, orchid id: 0000-0002-3102-0376.

Syamsul Bachri is a Ph.D., researcher and lecturer. Expert in Physical Geography, Disaster and Geography Education. Affiliation: Department of Geography Education, Faculty of Social Sciences, State University of Malang J1. Semarang No. 5, East Java, Indonesia. Email: syamsul.bachri.fis@um.ac.id. Scopus id: 48961044300, orchid id: 0000-0003-4576-5616.

Listyo Yudha Irawan is M.Sc., researcher and lecturer. Expert in Disaster, Geography Education and Watershed Management. Affiliation: Department of Geography Education, Faculty of Social Sciences, State University of Malang Jl. Semarang No. 5, East Java, Indonesia. Email: listyo.fis@ um.ac.id. Scopus id: 57202300595, orchid id: 0000-0002-9857-4460.

Muhammad Aliman is a Doctoral, and young researcher. Expert in Geography Education and Local Wisdom. Affiliation: Department of Geography Education, Faculty of Social Sciences, State University of Malang. J1. Semarang No. 5 East Java, Indonesia. email: muhammad.aliman.1607219@students.um.ac.id. Scopus id: 57210109291, orchid id: 0000-0001-9918-3991.

Wan Ibrahim Wan Ahmad is a Professor, researcher and lecturer at the Faculty of Health Sciences, Asia Metropolitan University, Jl Lembah, Bandar Seri Alam, 81750 Johor Bahru, Malaysia. Expert in Demography \& Development, Elderly Persons \& the family. email: wanibrahim@amu.edu.my. Scopus Id: 55214752000, Orcid Id: 00000001-9765-3822.

Article submitted 2021-01-08. Resubmitted 2021-02-23. Final acceptance 2021-02-24. Final version published as submitted by the authors. 